\title{
A Medialidade Hiperativa da Imagem Digital ${ }^{1}$
}

\section{The Hyperactive Mediality of Digital Image}

DOI: $10.46814 / \operatorname{lajdv} 3 \mathrm{n} 1-017$

Recebimento dos originais: 30/10/2020

Aceitação para publicação: 23/12/2020

\author{
Eduardo Louis Jacob \\ Doutor em Comunicação e Semiótica \\ Pontifícia Universidade Católica de São Paulo (PUC-SP) \\ Endereço completo: Rua Monte Alegre, 984 - Perdizes - CEP: 05014-901 - São Paulo-SP \\ E-mail: eljacob@pucsp.br
}

\section{RESUMO}

$\mathrm{Na}$ cultura digital não existe nenhum contexto claramente relacionado com a imagem, que se desterritorializa à medida que se propaga, descompromissada de produzir e impor um só sentido. A espacialidade da imagem já não remete a nada, somente a si própria e para a capacidade que o receptor terá que ter desenvolvido para decodificar a mensagem. A questão da medialidade digital é colocada com toda intensidade quando se verificam essas condições. $O$ estudo da medialidade da imagem parte de necessidade mais ampla que é refletir sobre a experiência visual ante a multiplicação medial das imagens. A imagem não possui um sentido imanente, mas o colhe pelo modo como constrói sua visualidade e mediante contato com o ambiente que abriga essa visualidade, quando se misturam nessa construção o meio, o medium e o ambiente informado, estabelecendo um circuito de mediações, no qual se envolvem produtores e espectadores, a sociedade e a cultura, a imagem e seus significados. Dado o seu caráter qualitativo e teórico, o texto visa trabalhar com noções coletadas a partir de autores da cultura digital (cibercultura) e do debate acerca da imagem, imprimindo um caráter interdisciplinar ao texto.

Palavras-Chave: Cibercultura, Imagem, Medialidade, Visualidade, Digital.

\begin{abstract}
In digital cultur there is no clearly related context with the image, which is deterritorialized as spreads, uncompromising to produce and impose only one sense. The spatiality of the image no longer refers to anything but itself and to the ability of the receiver will have to be developed to decode the message. The issue of digital mediality is placed at full intensity when these conditions occur. The study of image mediality derived from the wider requirement that is reflect on the visual experience face the medial multiplication of images. The image does not have an immanent sense, but only through the way it builds its visuality and through contact with the environment in which that visuality is situated, when mixing in this construction the medium, the media and the informed environment, establishing a mediation circuit, in which engage producers and viewers, society and culture, image and their meanings. Given its qualitative and theoretical character, the text aims to work with notions collected from authors of digital culture (cyberculture) and from the debate about the image, printing an interdisciplinary character to it.
\end{abstract}

Keywords: Cyberculture, Image, Mediality, Visuality Digital.

\footnotetext{
${ }^{1}$ Trabalho apresentado na Divisão Temática Ibercom Comunicação e Cultura Digital do XIV Congresso Internacional IBERCOM, na Universidade de São Paulo, São Paulo, de 29 de março a 02 de abril de 2015.
} 


\section{O DIGITAL ENTRE A TECNOLOGIA E A TÉCNICA: DIFERENÇAS FUNDAMENTAIS}

Em muitos sentidos, o debate em torno da pertinência tecnológica da cultura desse século tem monopolizado as atenções de muitos teóricos e tornado essa discussão um vórtice estonteante de sensos e contrassensos, posto que perdura desde há muito. Reconhece-se na tecnologia, de maneira geral, o elemento formador de uma consciência científica, que estaria na base da oposição entre homem e natureza.

Essa abordagem é bem desenvolvida por Argan (2005, p. 213), que enxerga na natureza a região do mito e do sagrado, aquilo que se encontrava fora dos limites dos muros da cidade, "o espaço não protegido, não organizado e não construído". Uma natureza plena de ameaças, inimiga, inacessível, habitada por animais e por Deus, identificada como "sublime", que representava "a fronteira entre o habitado e inabitável, entre o espaço geométrico e mensurável e a dimensão ilimitada, incomensurável do ser." (ARGAN, 2005, p. 213). O passo seguinte foi subjugar esse "sublime" transcendente pelo esforço tecnológico do homem, transferindo-lhe agora características tecnológicas, assim humanas, que submetem as forças cósmicas e as utilizam em seu proveito.

Argan (2005) argumenta que esse esforço tecnológico realiza-se sempre tendo como objeto a existência humana como existência social, por meio de um programa, um plano, um projeto que visa à mudança de uma situação de fato reconhecida como insatisfatória. Conclui ele que "não se planejaria ou projetaria se não se pensasse que a existência social será, deverá ou deveria ser diferente e melhor com relação ao que é” (ARGAN, 2005, p. 212). De modo que a tecnologia é fruto desse esforço em se pensar de modo diferente o que se está colocado e assentado, sendo evocada pelo "pensamento que a pensa" para modificá-lo.

Assim, a tecnologia é entendida aqui como "um saber-fazer que se sabe saber" (AMARAL, 1996, p. 17). A tecnologia não é um conjunto de aparatos técnicos produzidos pela ciência, mas implica uma visão de mundo baseada na técnica. Etimologicamente, o termo 'tecnologia' surge da junção entre techne e logos. Como explica Heidegger (1999, p. 46), techne "não significa nem arte nem técnica e sim um saber, a disposição competente de instituições e planejamentos bem como o domínio dos mesmos. A techne é criação e construção enquanto produção sapiente.” O acréscimo do logos na techne funda uma ordem do pensar baseada na lógica e na razão desse saber; entendimento também possível pela interpretação de Heidegger (1999, p.158), que entende o logos como a palavra, o discurso e principalmente "como reunião e unidade de reunião [...] que nunca é uma simples acumulação e amontoamento.”. Por esse motivo, a tecnologia é muitas vezes pensada no sentido de uma razão instrumental, como a que Escola de Frankfurt assegura-lhe ao vinculá-la à noção de progresso tecnológico, dando voz a uma crítica tradicional no ocidente, que é a ideia de controle associada à tecnologia. 
O sentido da palavra 'técnica' que percebemos hoje está mais distante da sua origem grega. Heidegger (2006, p. 12) reconhece aquilo que chama de diferença ontológica entre técnica e essência da técnica, separando a "determinação instrumental e antropológica da técnica", aquela que é um instrumento ou um meio utilizado pelo homem que serve a um fim, pertencendo a ela a produção e o uso de ferramentas que servem para manipular e dominar a técnica; a técnica como "desencobrimento" de um fim, "da causalidade à qual pertencem meio e fim". O traço fundamental, daquela técnica como provocação da natureza e do ser, dos perigos e ameaças que o predomínio da “com-posição", essência da técnica, "arrasta consigo a possibilidade ameaçadora de se poder vetar ao homem voltar-se para um descobrimento mais originário." (HEIDEGGER, 2006, p. 31). Como conclusão desse pensamento, Silva (2006) vê que a técnica cria uma ilusão de neutralidade e a verdade residiria na descoberta, pelo caminho da reflexão, de que a técnica tende a escapar do controle do homem para controlá-lo. Pela técnica, o homem transforma e é transformado, assim como pela técnica extraem-se os minérios da terra, modificando e devastando a terra escavada, alterando o próprio espaço.

O que trouxe de novo o meio digital? À primeira vista, estabelece um fluxo de informação muito mais intenso que seus predecessores, entre outros motivos, quando se converte em multimídia por incorporar os fluxos televisivos, radiofônicos e outros em uma só pista, que é a digitalização, promovendo uma convergência tecnológica dos meios de comunicação e seus anexos técnicos para o interior de seu próprio meio técnico e a instauração de um fluxo de conteúdo permanente e descentralizado. Assim como o branco é considerado tanto soma quanto ausência de cores e, stricto sensu, não poderia ser considerado cor, o meio digital tem comportamento análogo em relação aos meios que absorve e refrata. $\mathrm{O}$ meio digital constitui-se nesse movimento de absorção e refração de linguagens e a chave de seu entendimento está na compreensão do funcionamento dessa linguagem, no sentido de reconhecer nessa dinâmica tanto seus fatores conservadores, como aqueles que impulsionam as mudanças. Para isso, é necessário compreender o seu mecanismo operacional, identificado pela digitalização.

Digitalizar a informação é abstrair todas suas dimensões em bits, que não têm cor, tamanho ou peso. Pela digitalização, qualquer fonte de informação pode ser homogeneizada em uma cadeia sequencial de 0 a 1 . Ela se dá basicamente por dois processos distintos: conversão e sintetização, sendo possível, por meio dela, traduzir uma informação originalmente analógica em digital, convertendo seus sinais visuais ou sonoros de uma matriz elétrica ou impressa em uma curva de ondas, para o som, e em um mapa de bits, para as imagens de bitmap, quando qualquer informação, mesmo um texto escrito, transforma-se numa imagem pela interpretação do computador. Como a informação pode ser produzida diretamente no computador, os softwares assumem o comando (MANOVICH, 2008). É por meio dos 
softwares e da sua lógica de produção programada que as informações são operacionalizadas e as imagens, textos e sons são sintetizados.

O advento da digitalização é o acontecimento originário, por se tornar uma espécie de denominador comum dos novos compostos digitais, produzindo uma espécie de ruptura históricotecnológica com "um universo analógico da época industrial” (VILCHES, 2003, p. 258), no sentido em que todo tipo de informação - imagética, sonora, textual - passa a ser constituído em modo digital, ao qual muitos outorgam poderes de linguagem universal. Se, a princípio, a uniformização de toda informação por meio da digitalização representa um ganho extraordinário no sentido de facilitação na organização do conhecimento, lubrificando as trocas entre as linguagens e possibilitando a partir dessas misturas o surgimento de novos e surpreendentes artefatos visuais de caráter digital, induz, por outro lado, a uma perda da capacidade de diferenciação desse conhecimento, a uma dificuldade de reconhecimento dos modos distintos que o originaram, quando o diferente mascara-se de idêntico. Esse mascaramento é um fator que aumenta a confusão, ao instalar uma crise de identificação dos gêneros discursivos.

Como ressalta Kerckhove (2004, p. 57), “a uniformidade das unidades elementares obtidas por digitalização é verdadeiramente extrema: todos os bits são semelhantes" e arrisca uma possível maneira para encaminhar o entendimento: "somente sua ordem de aparição entre outros bits permite distinguilos.” A expressão ‘ordem de aparição' confere ao bit uma gênese fenomenológica que só pode ser percebida por meio de uma sequência, ou seja, enquanto série de bits, nunca unitariamente. Para o autor, "jamais o alfabeto nos conduziu a esse nível de fragmentação nem de abstração [...] [nem] nos tornou tão dependentes da ordem sequencial." (KERCKHOVE, 2004, p. 57). Um bit isolado não contém em si nenhuma indicação, como no dizer de McLuhan (1969) sobre a eletricidade - informação pura, um meio sem mensagem. É no processo de ordenação de bits, no seu sequenciamento, que se dá a transformação do bit em signo, um procedimento próprio da máquina e da sua programação, uma técnica que permanece oculta e da qual não participamos.

Entende-se que a imagem percebida em sua fenomenologia digital assume certas características específicas do meio digital. Ela encontra, nesse meio, condições extremamente favoráveis para o seu desenvolvimento e prolifera abundantemente. Além das boas condições ambientais possibilitadas pelo meio digital, encontra outras linguagens que povoam o mesmo meio técnico. Da miscigenação dessas linguagens, surge uma prolífera e criativa produção, que visa a explorar ao máximo suas possibilidades comunicativas, potencializadas pela sua ilimitada capacidade construtiva. Qualquer projeto que pretenda se posicionar criticamente frente ao estatuto da imagem digital precisa entender, antes de tudo, o funcionamento do mecanismo que orienta a formação dessas imagens. O princípio de conexão em rede traz a reboque a questão do fluxo informacional, comunicacional e imagético, que se torna mais 
relevante nos tempos digitais. Se antes eram debatidos dentro dos círculos fechados dos estudos dos media, quando o principal interesse estava ainda voltado para o meio televisivo com suas imagens pulsantes e massageadoras, agora, com o meio digital, os questionamentos sobre o fluxo alargam-se bastante, na mesma medida em que se afrouxam os limites que guarneciam seu entendimento. O fluxo não é uma corrente de ar disposta a circular por qualquer porta aberta, nem uma chuva que desaba sobre nós. Assim como não há rio que corra sem um leito, não há fluxo de informação que se estabeleça sem um sistema de escoamento, mesmo que este seja rizomático ou ramificado. Como visto anteriormente, o fluxo é da ordem do medium, portanto uma característica espacial e não do conteúdo que circula por ele. Fala-se em fluxo de conteúdo apenas porque o medium possibilita que certos conteúdos trafeguem por suas vias. O fluxo digital é um composto medium/conteúdo indissociável voltado à expansão das características visuais desse meio. É uma atividade originada no espaço criado pelo meio e patrocinada pela tecnicidade que o caracteriza.

\section{A TÉCNICA É UM MEIO QUE GERA OUTROS MEIOS}

O meio digital possibilita a integração de múltiplas linguagens num intenso jogo de combinação. Dentro desse playground ilimitado, parece que tudo se torna possível. Postman (2006, p.27) sublinha a questão de que "mudanças nos meios de comunicação induzem mudanças na estrutura da mente das pessoas ou mudanças na sua capacidade cognitiva" e, como resultado disso, a estrutura do discurso é modificada. Embora baseadas no estudo da televisão, suas declarações são altamente relevantes para o meio digital, como quando afirma que "mudanças no ambiente simbólico são como mudanças no seu ambiente natural.” (POSTMAN, 2006, p.27). Ele ainda sublinha o aspecto de que na televisão todo discurso público toma a forma de entretenimento, isto é, para ele, o tipo de conteúdo que é emitido em um meio é determinado pela capacidade particular daquele meio de formar seu conteúdo. Para o autor, "na televisão, o discurso é conduzido largamente pela imagética visual, o que quer dizer que a televisão nos dá conversação por imagens, não palavras.” (POSTMAN, 2006, p. 7). Seu principal argumento é que a forma exclui o conteúdo, no sentido de "cada medium, como a linguagem si mesma, faz possível um modo de discurso peculiar ao prover uma nova orientação para o pensamento, para expressão, para sensibilidade.” (POSTMAN, 2006, p.10). Sua preocupação, em meados dos anos 1980, tanto se traduzia em afirmar que a televisão enfatizava a satisfação de nossa necessidade de entretenimento em detrimento da qualidade da informação quanto em apontar para os efeitos da mudança de uma era tipográfica, da cultura escrita, para uma era da televisão, da cultura da imagem.

O meio digital não só é constituído para comunicar, mas constitui-se como a mais importante plataforma socioeconômica da atualidade, dividindo-se entre usuários profissionais e usuários com experiência de espectador passivo. Assim, consegue reunir múltiplas esferas de produção em torno da 
mesma plataforma técnica, constituindo a infraestrutura da comunicação e assumindo a coordenação dos outros grandes sistemas técnicos, colocando-se a serviço de outros fenômenos tecnossociais que tendem à integração mundial: finanças, comércio, pesquisa científica, mídias, transportes, produção industrial etc. (LÉVY, 2003), e, a partir da interconexão geral das informações, da máquina e dos homens, promove intensos diálogos e intercâmbios, um alcance inimaginável para a televisão. Para Vilches (2003), estamos diante de uma ruptura radical entre dois tipos de experiência de uso dos meios, como efeito da migração digital. Enquanto os espectadores de televisão obtêm uma experiência comunicativa que não exige nenhuma competência ativa, os usuários digitais, a partir da experiência interativa das novas mídias, são levados à ação pela mediação da tecnologia. $\mathrm{O}$ autor destaca que, possivelmente, o advento mais espetacular da migração digital tenha a imagem como protagonista, dado que recoloca em pauta a relação entre imagem e realidade.

$\mathrm{Na}$ cultura digital, o universal compartilhado em tempo real impossibilita a totalização, porque não existe nenhum contexto claramente relacionado com a imagem. A imagem desterritorializa-se à medida que se propaga, descontextualizando-se pela fragmentação exigida no processo e recontextualizando-se na interconexão, descompromissada com qualquer significação totalizante, ou seja, de produzir e impor um só sentido. A espacialidade da imagem nesse espaço de conexão está situada em nenhum lugar e está em todos os lugares, o que supõe uma desistoricização da experiência. Já não remete a nada, somente a si própria e para a capacidade que o receptor terá que ter desenvolvido para decodificar imediatamente a mensagem.

O registro da imagem pelo seu dispositivo de gravação está vinculado à tecnicidade do medium como indicador das atividades do meio técnico, operador responsável pela espacialização, organização da matéria e arranjo da camada simbólica na superfície que caracteriza a imagem, permitindo ao espaço tornar-se um meio para a existência fenomênica da imagem. A mediação técnica está presente em todos os espaços de imagens e participa das operações construtivas do meio, do medium, pelo suporte técnico, e do ambiente, ao se naturalizar no entorno do espectador.

O meio técnico é uma espécie de "unidade fabril" da comunicação, em que são produzidos, armazenados e colocados em movimento os objetos técnicos de caráter simbólico. Não se deve perder de vista que a imagem como artefato visual é um objeto técnico. Por esse entendimento, o meio técnico é o responsável pela reunião dos aspectos técnicos que envolvem o aparato tecnológico necessário para o comunicar.

Para entender plenamente suas características, é necessário recorrer à diferenciação aqui traçada entre meio e meio técnico, que são duas ocorrências distintas e interligadas. Segundo Thompson (2008, p. 26), "todos os processos de intercâmbio simbólico envolvem um meio técnico de algum tipo", uma espécie de codificador que rege a elaboração do conteúdo simbólico. Em sua obra, meio técnico é 
definido a partir dos elementos materiais pelos quais a informação ou conteúdo simbólico é fixado e transmitido, sendo que meio refere-se ao conjunto mais específico de instituições sociais e materiais necessárias para colocar em funcionamento o espaço de imagens. Dessa maneira, para cada meio, haverá sempre um meio técnico que opera de modo típico e peculiar. Por esse motivo, o meio técnico compreende atividades bem mais complexas que não a mera instrumentalização e montagem do suporte técnico, que ficam mais evidentes quanto mais tecnológicas são as exigências dos meios de comunicação, como no caso do meio técnico digital e dos objetos técnicos nele ensejados.

\section{MEDIALIDADE E IMAGEM DIGITAL}

Para flagrar a imagem no instante da gênese de sua corporalidade, é necessário entender suas estratégias ao se espacializar. Isso exige descobrir, no espaço das imagens, as condições de mediação que as levam a transmitir por meio do modo como se constroem (FERRARA, 2007). Como primeiro passo, é indispensável compreender que o comunicar é constituído por aquilo que se comunica e pelo como se comunica. Isso impõe a necessidade de superar a opacidade da imagem, pois "aquilo" que se comunica suplanta "o como" se comunica. A partir disso, passamos a entender o que permite às imagens apresentar algo que comunica, como também perceber que é no seu estado de ação em andamento, "em comunicando", que elas se apresentam à nossa percepção, o que supõe sua espacialização. Como bem resume Debray (2000), aprender o discurso pelo seu percurso, o que implica conhecer tanto aquilo que o discurso expressa quanto a maneira pela qual essa expressão é elaborada. Significa, em última instância, resgatar o lugar e o momento do comunicar e verificar a maneira como uma época constrói seu discurso, um retrato de si mesma, oculto nas entrelinhas e não explicitamente revelado pelo conteúdo do discurso.

Belting (2005) projeta seu estudo da imagem a partir de um receituário semelhante. Para ele, o "quê" de uma imagem é dirigido pelo "como" nela é transmitida uma mensagem. Esse "como" é a comunicação genuína, a verdadeira forma da linguagem da imagem, que é em grande extensão modelada pelo medium visual no qual ela reside. Para o autor, dentro da sua proposta iconológica, fazse necessário discutir tanto a unidade da imagem quanto a distinção de imagem e medium. Ele trabalha com a correspondência da relação medium-corpo e explica que medium é para ser entendido no sentido de agente pelo qual as imagens são transmitidas, enquanto corpo significa tanto aquilo que performatiza (o medium) quanto aquele que percebe (o espectador), dos quais as imagens dependem para comunicar.

Por esse aspecto, a imagem conecta dois corpos que se nutrem de atividades diferentes, mas complementares. O corpo participa de maneira múltipla: do lado da imagem, não só como portador da imagem, mas como produtor; do lado do espectador, como percepção da imagem de um "outro" e, como consequência disso, da sua própria imagem, como quem identifica algo distinto de si mesmo. 
Para Belting (2005), a autopercepção de nossos corpos (a sensação de que vivemos em um corpo) “é uma pré-condição indispensável para a invenção dos media, os quais podem ser chamados de corpos técnicos ou artificiais projetados para substituírem corpos por meio de um procedimento simbólico." (p. 306). Esse procedimento simbólico configura o medium da imagem, que é composto pelos seguintes elementos: um procedimento geral de simbolização (palavra, escrita, imagem analógica ou digital), um suporte material de inscrição e estocagem (argila, papiro, pergaminho, papel, canvas, banda magnética etc.) e um dispositivo de gravação (registro) conectado a uma determinada rede de difusão (tipografia, fotografia, televisão, fluxo informático).

O processo de espacialização da imagem dá origem à espacialidade, resultado de um processo construtivo que visa a habitar diferentes espaços, organizando-os à sua maneira. Essa espacialização da imagem só chega à sua configuração final quando atinge o corpo do participante que a visualiza; só ali a imagem adquire seu sentido. Portanto, a competência mediativa das imagens transcende o reino visual propriamente dito e alcança a visibilidade pelo contato com o imaginário do espectador. A imagem necessita da intervenção ativa da imaginação, enquanto capacidade de abstraí-la do medium que a suporta fisicamente e do ambiente que a acolhe, e torná-la visualizável, enquanto capacidade de prover um sentido a ela, entre as muitas possibilidades existentes.

O corpo das imagens é mais facilmente apreendido quando se trata de imagens tradicionais (impressa e eletrônica), mas será que se pode afirmar que a imagem digital possui um corpo? Nossa resposta é afirmativa, acompanhando Serres (2008, p. 33) quando diz que "codificação, formato e informação incluem-se, assim, na metafísica na qual o suporte substitui a substância.” Quer se trate de grafites em muros ou átomos no interior de uma célula, "encontramos a informação depositada sobre um suporte que, apesar de invariante em sua função, varia de textura", diz o autor (2008, p. 33). Participam, assim, do suporte digital: o código, o formato e a informação, e nesse conjunto surge a ideia de um corpo. Para Hansen (2006), é sobretudo na forma de imagem - mas também auditiva e tátil - que a informação digital é traduzida de forma apreensível, quando a informação torna-se perceptível, dando forma ou "in-forma" à informação. Nesse processo, afirma o autor, framing (enquadramento) torna-se crucial para todas as práticas nas novas mídias contemporâneas. O formato de que fala Serres (2008) e o enquadramento de Hansen (2006) equivalem-se, ao constituírem a primeira estratégia da imagem digital para se espacializar. A especificidade da imagem digital, para Belting (2005), está no abandono da mimesis do corpo refletido e seu endereçamento à imaginação dos nossos corpos. Nesse sentido, a tecnologia digital persegue a mimesis da nossa própria imaginação.

Assim, a imagem não possui um sentido imanente, mas apenas por meio do modo como constrói sua visualidade e mediante contato com o ambiente que abriga essa visualidade, quando se misturam nessa construção o meio, o medium e o ambiente informado, estabelecendo um circuito de mediações, 
no qual se envolvem produtores e espectadores, a sociedade e a cultura, a imagem e seus significados. Supera-se nessas propostas aquela condição que limita o estudo da imagem unicamente ao reconhecimento das suas formas semióticas e à interpretação dos sinais contidos na sua superfície visual, como também o dualismo imagem-representação, que articula a ligação entre a imagem e seu referente imediato.

Se tratamos das imagens e seus espaços, o estudo de Debray (1995) fornece-nos importantes elementos para entender a sua constituição. O autor afirma que "um medium desenvolve-se a partir do meio em que está inserido, quer este faça ou não a demanda.” (DEBRAY, 1995, p. 25). Percebemos que é no meio que as estratégias de elaboração do medium serão constituídas. Estabelece-se uma relação direta entre essas duas instâncias espaciais, a ponto de afirmarmos que não há medium sem meio e que todo meio necessita de um medium como plataforma operacional tecnológica para alcançar os grupos sociais que pretende afetar. Sem nenhum medium, as imagens deixam de estar no espaço social.

O registro da imagem é a matriz da visualidade, determinada pelo seu medium. Enquanto a construtibilidade apela para o espaço como estratégia determinante para a condição existencial da imagem, ensejando-a como espacialidade, a visualidade que resulta dessa operação volta-se à visão do espectador para que sejam promovidas sua identificação, leitura e interpretação. A visualidade está presente por causa e por meio do seu medium-corpo, sendo que a construtibilidade participa da montagem do seu medium e a visualidade participa como responsável direta pela performance do corpo da imagem para que outro corpo a perceba.

Instigada pela medialidade, a visualidade da imagem é responsável por alertar o observador da sua presença, de que há algo ali comunicável. A visualidade da imagem repousa na particularidade de sua medialidade. A capacidade mediativa da visualidade é quem estabelece o vínculo comunicativo com o observador, criando sua atenção, controlando sua percepção e negociando a interpretação de seu conteúdo. A imagem comunica sua comunicabilidade por meio de sua visualidade, cuja criação é responsabilidade dos processos associativos decorrentes da sua espacialização e determinantes de sua fisionomia.

A visualidade relaciona-se com o olhar do observador, exigindo deste ultimo ativa participação e inserindo-o em uma situação comunicativa que coloca em evidência o "aparecer" da imagem, com o “imaginar" e o "visualizar" do observador, perceber o visual e torná-lo visível, consolidando a ligação entre imagens endógenas e exógenas, ou seja, a conexão entre imagens físicas e imagens mentais.

A imagem necessita dessa ação da imaginação do observador como capacidade de decifrar imagens (FLUSSER, 2002) para adquirir significado, por meio de uma lógica imaginativa ou analógica, como "faculdade de variar as imagens, de combiná-las, de fazer que a parte de uma coexista 
com a de outra e de perceber, voluntariamente ou não, a ligação de suas estruturas" (VALÉRY, 2006, p. 23). Ou seja, da conexão de imaginários por caminhos associativos, quando cada um pode elaborar uma percepção particular dos fenômenos em um dado momento e recriar, a partir do seu próprio repertório, o universo significativo da imagem, donde seu caráter relativo, pouco afeito a uma comparação estrutural genérica. Para Belting (2007), essa percepção está sujeita a mudanças culturais, relacionadas à época em que ocorrem, na qual participa o enfoque medial das imagens, determinado pelas condições do momento no qual as imagens são modeladas. Assim, a ambivalência existente entre imagem e medium é dada pelas correspondências que se formulam novamente para cada caso concreto, com uma multiplicidade quase ilimitada.

O trabalho de Crary (2006) serve-nos de parâmetro ao explorar essa condição, concentrando sua atenção naquilo que chama de "modernização da percepção", ao afirmar que as mudanças não ocorrem na visão ou na percepção em si, mas nas forças e regras plurais que compõem o campo em que ocorre a percepção. Para ele, o que determina a visão em determinado momento histórico não é uma estrutura profunda, econômica ou de visão de mundo, mas, sim, "o funcionamento de um agenciamento coletivo de peças díspares em uma única superfície social.” (CRARY, 2006, p. 6). É importante ressaltar a importância dada pelo autor aos processos coletivos de enunciação em uma dada situação espaçotemporal, em detrimento de uma qualidade enunciativa específica do aparelho (dispositivo) em estudo, citando Deleuze e Guattari (2002, p. 31) quando afirmam que "uma sociedade se define por seus amálgamas e não por suas ferramentas. [...] estas só existem em relação às misturas que tornam possíveis ou que as tornam possíveis."

Em seu estudo, Crary (2006) emprega a câmera obscura como sistema e modelo paradigmático no status dominante do observador dos séculos XVII e XVIII, quando a produção da imagem fazia referência a leis ópticas ligadas a uma física dos raios luminosos de base newtoniana, sem qualquer interferência humana. A câmera obscura portava em si o pensamento do projeto de racionalidade hegemônica da qual foi fruto e disseminadora, funcionando como espécie de a priori, em que só havia uma relação de exterioridade entre sujeito e objeto. Como ruptura a esse movimento, o autor recorre à exemplificação de vários aparelhos que precederam à invenção da fotografia, principalmente ao stereoscope, para ilustrar a passagem dessa ótica geométrica para uma ótica psicológica no século XIX e mostrar como esses "aparatos são o resultado de um complexo refazer do indivíduo como observador em algo calculável e regulável e da visão humana em algo mensurável e, portanto, permutável.” (CRARY, 2006, p. 17). Em sua obra, há o abandono deliberado de um determinismo tecnológico fundado nas noções de progresso e desenvolvimento. Segundo ele, ao utilizar o conceito de modernização fora da reflexão teórica e da conotação habitual que inclui as noções de "racionalização" e "reificação", torna-se possível chegar a outra noção, que envolve transformações não lineares, às 
quais são associadas características "pós-históricas", uma vez vencidas as barreiras da causalidade e do processo unitário da história.

Por força desses aspectos, Crary (2006) crê que o rápido desenvolvimento de uma vasta gama de "técnicas de computação gráfica", assim como das "imagens computacionais", possibilitou uma transformação na natureza da visualidade provavelmente mais profunda do que a fratura que separou o imaginário medieval da perspectiva renascentista, que obrigou a reconfiguração das relações entre "um sujeito observador e os modos de representação que efetivamente anula a maioria dos significados culturalmente estabelecidos dos termos observador e representação." (CRARY, 2006, p. 1). Seu trabalho situa-se em torno da construção histórica da visão. Sua empreitada dá-se em reconsiderar e reelaborar parte do pano de fundo histórico da visualidade, focando no seu estudo uma reorganização anterior da visão, particularmente da primeira metade do século XIX, e esboçando alguns dos eventos e forças que produziram um novo tipo de observador, que, para ele, funcionam como precondições para o atual andamento da abstração da visão vivenciada pela tecnologia digital.

A lógica imaginativa, que deriva da mediação da experiência visual proporcionada atualmente pelos meios digitais, modifica as bases nas quais se acredita assentar os parâmetros da racionalidade vigentes orientados por princípios de linearidade, ordem e certeza, concebidos principalmente a partir da invenção da escrita e radicalizados pela prensa mecânica reprodutora dessa escrita, que, se extrapolada aos domínios dos processos socioculturais, promove uma necessária readequação de hábitos e costumes.

Para dar conta dessa situação nova, o homem precisa aperfeiçoar habilidades perceptivas específicas que consigam formular sentido dentro desse contexto. A habilidade que é colocada em evidência é a do pensamento visual (ARNHEIM, 1997), aquele capaz de atuar na ausência da linguagem verbal, de gerar sentido sem o apoio da palavra. Todas as imagens estão diretamente relacionadas a uma articulação de um pensamento visual com a percepção humana. Essa abordagem procura explicitar o processo pelo qual o indivíduo percebe o seu ambiente e o seu tempo, com base na interação da percepção sensorial em conjunto com as estruturas internas de pensamento. Os aspectos que fazem alusão ao cotidiano estão refletidos nas imagens, devidamente colocados sob investigação pela percepção. O pensamento visual incorpora a consciência do mundo e a consciência de si mesmo, nos traçados imaginários das histórias pessoais de cada um, que se identificam com as histórias contadas por aquela realidade medial.

Essas condições implicam considerar a hegemonia da visão na cultura contemporânea. A visão confirma-se como o sentido dominante entre os modos de percepção, pelo menos na condução de nossas vidas cotidianas. Para Levin (1997), essa questão abre-se para o pensamento que utiliza o argumento do paradigma visual na história cultural em termos de hegemonia e dominação, lembrando 
o ocularcentrismo típico da modernidade. Não somente por esses aspectos, a visão é confundida como a principal fonte de certezas e de cognição, desde os antigos gregos, como Heráclito que afirmava que “os olhos são sentidos mais confiáveis do que os ouvidos", até a invenção da representação em perspectiva, que tornou os olhos o ponto central do mundo perceptual (PALLASMAA, 2011). Na nossa cultura, especialmente a ocidental, a visão é tida como aquilo que fornece acesso imediato ao mundo exterior e, por conta disso, confundida como fonte privilegiada de cognição.

Levin (1997, p.212) envereda por essa análise e sublinha a tendência à autonomia e agressividade da visão, afirmando que "a vontade de poder é muito forte na visão. Há uma tendência muito forte na visão a agarrar e a fixar, a reificar e a totalizar: uma tendência a dominar, garantir e controlar $[\ldots]$ para manter a racionalidade instrumental de nossa cultura"

O que nos importa ressaltar é como o ver do espectador pode ser controlado pela ação do meio. Essa ação, de iniciativa do meio, controla o medium, com a intenção de ganhar alguma prevalência no ambiente informado

Uma amostra desse enfoque pode ser encontrada na aplicação de Jay (1999) do termo 'regime escópico', cunhado pelo teórico francês do cinema Metz (1980), em que faz a distinção entre cinema e teatro, da relação entre cinema e voyeurismo, e da maneira como este se preocupa em manter uma abertura, um espaço vazio, entre o objeto e olho, o objeto e o corpo, mantendo o cuidado de reter o objeto à distância ideal. Trata-se de uma localização cultural da visão e da visualidade, ampliando o alcance do campo escópico de Lacan para o regime escópico, algo como o modo "socialmente instituído" de olhar para o que é próprio do olhar cinematográfico.

Dessa maneira, Jay $(1999$, p.3) toma emprestado o termo e o aplica para estudar os "regimes escópicos da modernidade”, partindo da dúvida se há um único e unificado regime escópico da modernidade ou se existem muitos, que possivelmente competem entre si. Em sua resposta, afirma que o regime escópico pode ser caracterizado pela diferenciação de subculturas visuais, cuja separação permite compreender as múltiplas implicações da visão. Portanto, o autor adota o termo de Metz (1980), mas a aplicação é bastante diferente. Isso nos leva a pensar que o significado do regime escópico é não só o "próprio" de um medium, como era o filme e o cinema de Metz (1980), mas, sim, o "próprio" de uma época ou o seu modelo particular dominante. Dessa maneira, o visível da imagem, ancorado no medium criado para ela, forma um conjunto indissociável de complexa apreensão, entendido como um caso particular ou singularidade, possível de ser capturado quando prestamos atenção aos sinais e indícios presentes nesse conjunto.

A medialidade da imagem é, então, o resultado de um processo mediativo iniciado no interior da imagem, para o qual a visualidade ofusca-nos pelo brilho com que ilumina a linguagem ávida pelo comunicar. Esse processo mediativo alia a performance operativa do meio técnico com o agir humano 
pleno de intenções comunicativas. A visualidade da imagem repousa na particularidade de sua medialidade. Para entendê-la, são necessários o estudo sobre o meio e as maneiras com as quais os meios modulam os fins, medium e ambiente. Belting (2005) diz que a política das imagens reside na sua medialidade, pois esta normalmente é controlada por instituições e serve ao interesse do poder político. Não circunscrita a esse aspecto, a medialidade, quando desencoberta e revelada, permite-nos encaminhar uma série de questionamentos, que normalmente não são dirigidos à imagem, pois a medialidade não é evidente.

A medialidade é a responsável pelo regime de expressão da imagem e, por vezes, confundemse. Ela trabalha entre uma materialidade ainda não estruturada, todas as suas possibilidades de organização (a construtibilidade) e a instalação de uma visualidade, que fará a mediação com o espectador. Sua capacidade é de selecionar o que entra ou não no campo visível do medium, funcionando como mediador para a seguinte mediação da visualidade. Quando indagamos se uma obra é aberta ou interativa ou se a observação que ela oferece é participativa ou impositiva, estamos interrogando a respeito da medialidade da obra. Está lado a lado com a construtibilidade, com a qual se confunde na sua ação. A medialidade, nesse sentido, também não é substituível pela materialidade das imagens, como tem sido costume na antiga distinção entre forma e matéria (BELTING, 2005). Ainda, corresponde ao pensar que está no fazer. O que faz com que uma imagem cumpra seu destino e adquira uma identidade especial? Poderíamos relacioná-la, então, ao que Rancière (2012, p. 110) chama de pensatividade da imagem, "como o nó entre várias indeterminações", que corresponde a esse imenso campo do possível com que a medialidade tem que trabalhar, uma tensão entre vários modos de representação.

Esse pensar do fazer exige decisões e está, portanto, relacionado com a mesma noção de poder que Levin (1997) entende existir na visão. Está também relacionado com o regime escópico de uma época, com a possibilidade de se determinar e controlar uma percepção pelas imagens. Uma ideia correspondente é apresentada por Grusin (2010) ao relacionar a medialidade com o conceito de governamentalidade de Foucault (2008), dentro de um contexto de práticas mediáticas, e suas interações, que funcionam tanto social quanto politicamente. Grusin cita um trecho que consta no texto de Foucault (2008) como origem de sua explicação sobre essa noção: "governo é uma correta disposição das coisas que se assume o encargo para conduzi-las a um fim conveniente." (GRUSIN, 2010, p. 73). Ainda, vê nessa "correta disposição das coisas" o modo como a governamentalidade está preocupada não apenas com pessoas ou populações, mas com coisas, mercadorias, produção, infraestrutura, informação etc. ou, mais precisamente, uma rede de pessoas e coisas. As práticas mediáticas serviriam, então, como técnicas de poder numa sociedade de controle. 
A medialidade não se relaciona apenas com dominação política, mas também com a conquista da preferência dos espectadores, entre outros pontos passíveis de serem destacados. O questionamento atual dos produtores de imagens a respeito da mobilidade entre vários media pelos espectadores, mostra a preocupação do meio com os ambientes vivenciais dos espectadores e com a exponibilidade efetivamente ensejada nesses ambientes. 


\section{REFERÊNCIAS}

ARGAN, Giulio Carlo. História da arte como história da cidade. 5.ed. São Paulo: Martins Fontes, 2005.

ARNHEIM, Rudolf. Visual Thinking. Berkeley: University of California Press, 1997.

BELTING, Hans. Antropologia de la Imagen. Buenos Aires: Katz Editores, 2007.

Image, Medium, Body: A New Approach to Iconology. Critical Inquiry; 31, 2; p. 302 -319, 2005.

CRARY, Jonathan. Techniques of the Observer: On Vision and Modernity in the Nineteenth Century. Cambridge: The MIT Press, 2006.

D’AMARAL, Marcio Tavares. (org.) Contemporaneidade e novas tecnologias. Rio de Janeiro: Sette Letras, 1996.

DEBRAY, Régis. Manifestos Midiológicos. Petrópolis: Vozes, 1995.

Transmitir. Petrópolis: Vozes, 2000.

DELEUZE, Gilles. Conversações: 1972-1990. Rio de Janeiro: Ed.34,1992.

DELEUZE, Gilles; GUATTARI, Félix. Mil Platôs. 5vol. Rio de Janeiro: Ed 34, 2002.Flusser (2002).

FERRARA, Lucrécia D’Alessio (org.). Espaços Comunicantes. São Paulo: Annablume; Grupo Espacc, 2007.

FLUSSER, Vilém. Writings. Minneapolis: University Minnesota Press, 2002.

FOUCAULT, Michel. Microfísica do Poder. Rio de Janeiro: Edições Graal, 2008.

GUMBRECHT, Hans Ulrich. Corpo e forma: ensaios para uma crítica não-hermenêutica. Rio de Janeiro: EdUERJ, 1998

GRUSIN, Richard. Premediation: affect and mediality after 9/11. New York: Palgrave Macmillan, 2010.

HANSEN, Mark. New Philosophy for New Media. Cambridge: The MIT Press, 2006.

HEIDEGGER, Martin. Ensaios e Conferências. 3.ed. Petrópolis, RJ: Vozes, 1999.

JAY, Martin. Scopic Regimes of Modernity. In: FOSTER, Hal (ed.). Vision and Visuality. Seattle: Bay Press, 1999.

KERCKHOVE, Derrick de. O senso comum, antigo e novo. In: PARENTE, André (org.). Imagem-máquina. 3.ed. Rio de Janeiro: Ed. 34, 2004.

LEVIN, David Michael. (ed.). Modernity and the hegemony of vision. Berkeley: University of California Press, 1997.

LÉVY, Pierre. Cibercultura. 2.ed. São Paulo: Ed. 34, 2003.

MANOVICH, Lev. Software takes command. [2008]. Disponível em: <http://manovich.net/articles/ > Acesso em 13/09/2011.

MCLUHAN, Marshall. Os meios de comunicação como extensões do homem. São Paulo: Cultrix, 1969. 
METZ, Christian. O Significante Imaginário. Lisboa: Livros Horizonte, 1980.

PALLASMAA, Juhani. Os olhos da pele: a arquitetura e os sentidos. Porto Alegre: Bookman, 2011.

POSTMAN, Neil. Amusing ouservelves to death: public discourse in the age of show business. New York: Penguin Books, 2006.

RANCIÈRE, Jacques. O espectador emancipado. São Paulo: Editora WWF Martins Fontes, 2012.

SERRES, Michel. Ramos. Rio de Janeiro: Bertrand Brasil, 2008.

SILVA, Juremir Machado. As tecnologias do imaginário. 2.ed. Porto Alegre: Sulina, 2006.

THOMPSON, John B. A mídia e a modernidade: uma teoria social da mídia. 10.ed. Petrópolis: Vozes, 2008.

VALÉRY, Paul. Introdução ao método de Leonardo da Vinci. São Paulo: Ed. 34, 2006

VILCHES, Lorenzo. A Migração Digital.Tradução: Maria Immacolata Vassalo de Lopes. São Paulo: Edições Loyola, 2003. 